\title{
Daniel Tollet, Être juif en Pologne. Mille ans d'histoire. Du Moyen Âge à 1939
}

Paris, Éditions Albin Michel, 2010, collection « Présences du judaïsme », $328 \mathrm{p}$.

Jacques Gutwirth

\section{(2) OpenEdition}

Journals

Édition électronique

URL : http://journals.openedition.org/assr/22972

DOI : $10.4000 /$ assr.22972

ISSN : $1777-5825$

Éditeur

Éditions de l'EHESS

Édition imprimée

Date de publication : 31 décembre 2011

Pagination : 284

ISBN : 9782713223273

ISSN : 0335-5985

Référence électronique

Jacques Gutwirth, «Daniel Tollet, Être juif en Pologne. Mille ans d'histoire. Du Moyen Âge à 1939 »,

Archives de sciences sociales des religions [En ligne], 156 | octobre-décembre 2011, document 156-108, mis en ligne le 17 février 2012, consulté le 21 septembre 2020. URL : http://journals.openedition.org/ assr/22972 ; DOI : https://doi.org/10.4000/assr.22972

Ce document a été généré automatiquement le 21 septembre 2020.

(c) Archives de sciences sociales des religions 


\title{
Daniel Tollet, Être juif en Pologne. Mille ans d'histoire. Du Moyen Âge à
} 1939

Paris, Éditions Albin Michel, 2010, collection « Présences du judaïsme », $328 \mathrm{p}$.

\author{
Jacques Gutwirth
}

\section{RÉFÉRENCE}

Daniel Tollet, Être juif en Pologne. Mille ans d'histoire. Du Moyen Âge à 1939, Paris,

Éditions Albin Michel, 2010, collection « Présences du judaïsme », 328 p.

1 En 1992, l'auteur a publié Histoire des juifs en Pologne du XVIe siècle à nos jours. Ce livre n'étant plus disponible et l'historiographie polonaise et ses sources s'étant considérablement renouvelées, surtout depuis la chute du socialisme, Daniel Tollet propose une nouvelle version de ce livre, en principe plus synthétique.

2 Cet ouvrage transformé est en tout cas d'une grande richesse et il nous apprend mille détails sur la vie économique et religieuse des juifs, sur les discriminations qu'ils ont subies, etc. Mais peut-on vraiment parler de synthèse? Celle-ci est d'ailleurs fort malaisée, étant donnée la variété des situations féodales et des circonstances historiques dans les différentes régions de Pologne, soumises le plus souvent au cours des siècles à des pouvoirs changeants - russe, autrichien, prussien, et même suédois avec leurs lois et exigences diverses, jusqu'à l'indépendance unificatrice polonaise, enfin acquise après la première guerre mondiale.

3 Sur le plan proprement religieux, l'auteur présente la diversité des mouvements sabbatianisme, frankisme, hassidisme - qui apparaissent surtout après ce que l'on a appelé «le déluge", avec les révoltes des cosaques et leurs persécutions antijuives entre 1648 et 1654. La Pologne connaît aussi l'influence des Lumières puis des idées assimilantes et du socialisme, parmi les non-juifs comme parmi les juifs, ce qui suscite 
contre les « éclairés » et les incroyants de virulents anathèmes de la part des autorités rabbiniques orthodoxes, dont toutefois le pouvoir s'amenuise au fil des siècles.

4 On perçoit aussi dans ce livre le rôle important qu'ont joué les juifs dans le développement de l'économie du pays, dans son commerce international, en tant qu'artisans, également comme médecins, etc.

5 Les persécutions et discriminations diverses, les accusations de meurtres rituels, de profanations d'hosties, de sorcellerie - pour lesquelles on les associe maintes fois aux réformés - sont présentes jusqu'à la fin du XIX siècle, par exemple en 1886 à Cracovie.

6 L'auteur arrête son historique en 1939, et on sait que de 1939 à 1945 l'histoire déjà dramatique des juifs en Pologne s'achève tragiquement avec le massacre incommensurable de neuf dixièmes d'entre eux par les Allemands.

$7 \mathrm{Au}$ total il s'agit d'un livre remarquablement documenté et érudit, importante contribution à une histoire dont les multiples ressorts sont encore loin d'être déjà tous découverts. 